\title{
OBITUARIES
}

\section{Prof. H. V. A. Briscoe}

Henry Vincent Aird Briscoe died in London after a short illness on September 24, 1961, his seventy-third birthday. He was professor of inorganic chemistry in the University of London at the Imperial College of Science and Technology during 1932-54 and thereafter professor emeritus and Fellow of the Imperial College. Briscoe was educated first at the City of London School and then the Royal College of Science, which at the time was on the point of being incorporated within the framework of the Imperial College. He graduated with honours in chemistry and then first assisted. Sir Edward Thorpe in a revision of his Dictionary. Although he was still a junior member of the teaching staff of the Imperial College, during the First World War he was engaged in responsible and secret work (which similarly occupied much of his time during the Second World War) and later took charge of the Organic Chemistry Department at Sir John Cass College before being appointed in 1921 to the chair of inorganic and physical chemistry at Armstrong College (now King's College), Newcastle upon Tyne. He became head of the Chemistry Department in 1925 and later served as dean of the Faculty of Science in the University of Durham. Six years following his return to the Imperial College, on the retirement of Prof. J. C. Philip, he became director of the Laboratories of Inorganic and Physical Chemistry, a position he held until his retirement.

In addition to his academic positions, Briscoe had many outside interests: arnong other things he was the first director of the Northern Coke Research Committoe's laboratory, president of the Research Association of British Paint, Colour and Varnish Manufacturers, visitor and manager of the Royal Institution of Great Britain and Ireland, vice-president of the Royal Institute of Chemistry, as well as being a member of Council and officer of tho Chemical Society, and chairman of a local section of the Society of Chemical Industry. After the Second World War he was also greatly concerned with the improvement of the supply of laboratory technicians in university work and was chairman of the Imperial College Technician Training Committee, of the similar University of London Committee and of the National Joint Committee on the Recruitment and Training of Science Laboratory Technicians.

Briscoe's scientific publications cover a wide range of interests. Although his first publication in 1912 with P. W. Robertson was on the migration of the para-halogen atom in phenols, he afterwards moved into the inorganic and physical area. Among his oarlier works were precise atomic woight determinations of vanadium, tin, thallium, boron and bromine. Ho considered himself a disciple of T. W. Richards and was similarly devoted to rigorous purification and the development of new methods, such as those for handling volatile hydrolysable halides. He was also aware of the possibility of the variation in isotopic ratios of materials of differont geological origin, and for his studies on boron developed a flotation method for the measurement of comparative densities of boron trichloride which gave values to within about $\pm 2 \times 10^{-6}$ unit. This density method, which was typical of Briscoe's experimentel skills and ingenuity, was also applied to examine heavy water and he was among the first in Great Britain to be concerned with the use of deuterium and later oxygen-18 as tracers in exchange reactions. Briscoe also made contributions to the chemistry of rhenium oxides, halides and sulphides, and of selenium.

Throughout his eareer, Briscoe was much concerned with more applied aspects of chemistry and made many contributions to the knowledge of coke, paints and drying oils, on which he was an authority, purity of water, insect pests in foodstuffs, etc. During the 1930's he became very interested in the silicosis problem and hazardous industrial dusts and devised methods for collection and analysis of dust samples. For this work he was awarded the Consolidated Goldfields of South Africa Medal by the Institution of Mining and Metallurgy. Inspired by a lecture given by Langmuir at the College, and anticipating current interest by many years, he also worked with Sebba on the reduction of evaporation from water surfaces through the use of monolayers of cetyl alcohol.

Briscoe will be remembered by his colleagues and students for his approachability and kindly manner. $\mathrm{He}$ is survived by his wife and a son and daughterboth members of the medical profession.

G. WILKInson

\section{Prof. Carl Hermann}

Prof. Carl Hermann, director of the Crystallographic Institute at the University of Marburg, died unexpectedly in his sleep on September 12 at the age of sixty-three. He was a pupil of Max Born and a fellow research student with Werner Heisenberg, at Göttingen. Later he became a lecturer at Stuttgart, where he and Paul Ewald initiated the Strukturberichte which (with its successor Structure Reports) gives a detailed abstract of every known crystal structure determination, and which is a valued work of reference in every modern scientific library. $\mathrm{He}$ also developed, with Prof. C. Mauguin, a systematic nomenclature (now known as the Hermann-Mauguin notation) for the 230 space groups, from which the symmetry can be derived at a glance; and he travelled widely in the early 1930 's, gathering material for the two volumes of the Internationale Tabellen zur Bestimmung von Kristallstrukturen.

Hermann and his wife Eva wero guests in my home at the time when the National Socialist party doubled its strength in the General Election of June 1932, which later brought Hitler to power; and I ean well remember their dismay, for they realized even then what would follow. Later, Carl Hermann refused to conform to the political conditions imposed on academic staff and he took a position as physicist at the I.G. Farbenwerke at Ludwigshafen, where he continued crystallographic research of high quality on the nature of chemical bonds and on symmetry in $n$-dimensional space. He and his wife were imprisoned throughout much of the Second World War for their increasing activities in hiding and helping innumerable Jews to escape from the terrors of Nazi persecution. Only his eminence as a scientist 